ACTA MYCOLOGICA

Vol. 44 (2): 211-222

2009
Dedicated to Professor Krystyna Czyżewska

in honour of 40 years of her scientific activity

\title{
The lichen family Parmeliaceae in Poland. I. The genus Parmotrema
}

\author{
AGNIESZKA JABŁOŃSKA, MAGDALENA OSET and MARTIN KUKWA
}

Department of Plant Taxonomy and Nature Protection

University of Gdańsk, Al. Legionów 9, PL-80-441 Gdańsk

agnieszkajablonska82@wp.pl

Jabłońska A., Oset M., Kukwa M.: The lichen family Parmeliaceae in Poland. I. The genus Parmotrema. Acta Mycol. 44 (2): 211-222, 2009.

The paper presents the results of study on four Parmotrema species in Poland, P. arnoldii, $P$. crinitum, $P$. perlatum and $P$. stuppeum. They are mainly known from southern part of the country, mostly in the Carpathians. $P$. perlatum is reported also from Northern Poland and Central Poland. For $P$. stuppeum, so far known from single locality only, three new sites are reported. All the species seem to be rare and endangered in Poland. This work is the first part of a larger series which will present data on selected genera of the lichen family Parmeliaceae in Poland.

Key words: Parmotrema, Parmeliaceae, chemotaxonomy, foliose lichens

\section{INTRODUCTION}

The lichen family Parmeliaceae Zenker (Lecanorales, Lecanoromycetes, Ascomycota; see Lumbsch, Huhndorf 2007) comprises several genera of mostly foliose, but also few fruticose and crustose lichens (e.g., Elix 1993; Lumbsch, Huhndorf 2007), and recently even the lichenicolous genus Phacopsis Tul. was proved to belong to the family (Peršoh, Rambold 2002). Parmeliaceae is morphologically and chemically very diverse group of lichens, but generally it is characterized morphologically by a type of apothecial ontogeny and the presence of an ascomatal structure called a cupulate exciple (Blanco et al. 2006 and literature cited therein).

The family comprises about 1500 species and is thought to be one of the richest in species within lichenized Ascomycota (Blanco et al. 2006). It is also one of the most widely discussed group of lichens in terms of generic delimitation. For a long time only few genera were accepted, but extensive research, mostly by M. E. Hale Jr. (cf. Hale 1974a, b, 1975, 1976a, b, c, 1986), led to segregation of morphologically and chemically more homogenic groups. However, those taxonomic concepts were 
not always followed and all segregates treated as doubtful (e.g., Purvis et. al. 1992). Recently, the taxonomy of Parmeliaceae has been studied with molecular tools, and the importance of chemical, morphological and anatomical diagnostic characters have been re-evaluated (e.g., Blanco et al. 2004a, b, 2005; Divakar et al. 2006). Numerous Hale's genera and those distinguished later by other lichenologists are still accepted, however, some of them appeared to be synonyms (Blanco et al. 2004a, b, 2005; Divakar et al. 2006).

Parmotrema A. Massal. is one of the genera accepted at present, however in a wider sense then previously, as it also includes Canomaculina Elix \& Hale, Concamerella W. L. Culb. \& C. F. Culb., Parmelaria Awasthi and Rimelia Hale \& Fletcher, which were found to be phylogenetically nested within Parmotrema s.str. (Blanco et al. 2005). The genus is characterized by usually large foliose thalli with ciliate or eciliate margin, lack of pseudocyphellae, upper cortex consisting of a palisade plectenchyma (or rarely paraplectenchyma), pored or fenestrated epicortex, laminal, perforate or eperforate apothecia and usually simple rhizines (Blanco et al. 2005).

As many Parmotrema species are very similar in morphology, the secondary chemistry plays an important role in the identification and taxonomy of these lichens. The substances found in this genus comprises atranorin and rarely usnic acid, which are present in the cortex, and several medullary compounds belonging to orcinol depsides, orcinol depsidones, $\beta$-orcinol depsides, xanthones, aliphatic acids, pulvinic acid and derivatives and antraquinones (cf. Hale 1965; Blanco et al. 2005). For the determination of them colour reactions with simple chemical reagents $(\mathrm{C}, \mathrm{K}$ and PD) were used in Poland, however this method is not very reliable, as it can not distinguish lichen substances with the same type of reaction. For that reason specimens should be studied by thin-layer chromatography (TLC) .

Until now 4 taxa have been reported in Poland (Fałtynowicz 2003), and almost all of them have not been confirmed by TLC. Some species were consider to be rather common, e.g., P. perlatum (Huds.) M. Choisy, but some were very rarely reported from few stands only, e.g., $P$. stuppeum (Taylor) Hale. Our unpublished results show that frequency for some taxa is different.

The aims of this paper, the first dealing with the revision of selected genera of the family Parmeliaceae in Poland, are to present the result of studies on the morphology, chemistry, distribution and habitat requirements of the genus Parmotrema in the country.

\section{MATERIAL AND METHODS}

The present study is based on collection which are deposited in Polish lichen herbaria (KRAM, KRAP, KTC, LBL, UGDA). The morphology of the specimens were examined under the stereo microscope for thallus colour, shape of lobes, presence and abundance of cilia, and the type of soralia and isidia. The lichen substances were investigated by thin layer chromatography (TLC) following the methods described by Orange et al. (2001). The chromatograms were developed in solvent $\mathrm{C}$. 
All examined localities are mapped according to the ATPOL grid square system (Zając 1978; modified by Cieśliński, Fałtynowicz 1993; see also Kukwa et al. 2002).

\section{RESULTS}

Parmotrema arnoldii (Du Rietz) Hale, Phytologia 28: 335 (1974).

Syn. Parmelia arnoldii Du Rietz, Nyt Mag. Naturvidensk. 62: 80 (1924) .

Characteristic of the species. Parmotrema arnoldii is distinguished by the sublaminal soredia developing mostly at laciniae, narrow, mostly black non-rhizinate marginal zone, usually sparsely ciliate thallus margin and the presence of atranorin, alectoronic and $\alpha$-collatolic acids, sometimes accompanied also by skyrin (= rhodophyscin). Cortex reacts $\mathrm{K}+$ yellow and medulla is $\mathrm{KC}+$ pink-red, $\mathrm{UV}+$ ice-blue, $\mathrm{C}-$ and PD- (Hale 1965; Louwhoff 2009a). In Polish specimens all substances, except skyrin, were found.

Affinities. The species is distinguished from morphologically similar taxa producing soredia by the production of alectoronic and $\alpha$-collatolic acids. There is no other species of Parmotrema with these substances in Europe (Hale 1965), however this substances are produced in the morphologically somewhat similar Cetrelia chicitae (W. L. Culb.) W. L. Culb. \& C. F. Culb. This species differs in the presence of pseudocyphellae and eciliate thallus margin (Obermayer, Mayrhofer 2007).

Habitat requirements. According to Louwhoff (2009a) P. arnoldii usually grows amongst epiphytic mosses, especially on horizontal branches of trees and old shrubs

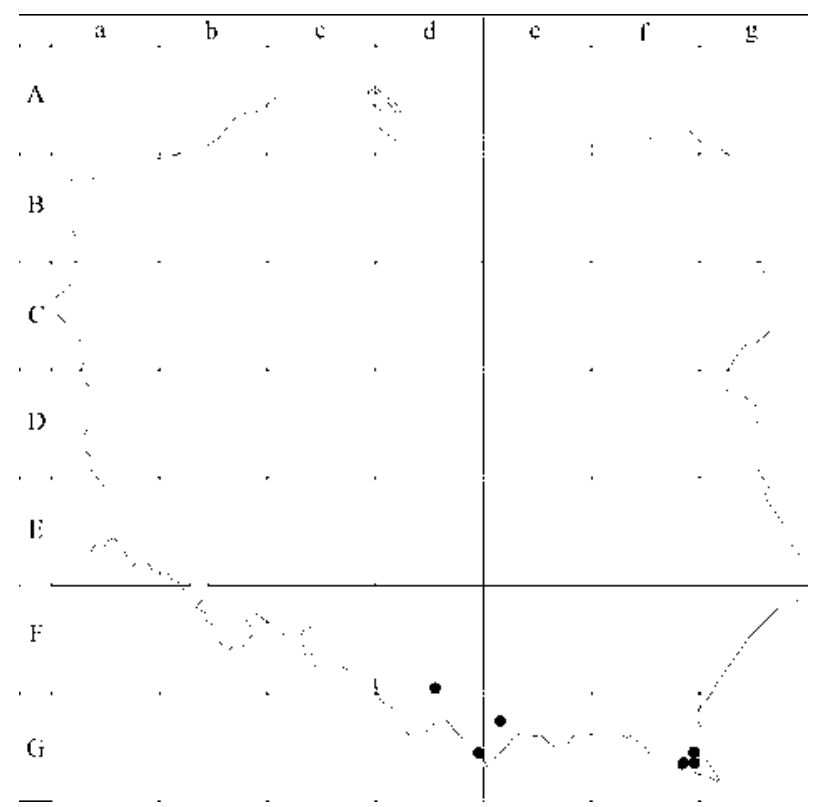

Fig. 1. Distribution of Parmotrema arnoldii in Poland in the ATPOL grid square system. 
in \pm well-lit, mild and humid, undisturbed woodlands. In Poland this lichen was collected on Acer spp., Alnus spp., Fagus sylvatica, Fraxinus excelsior and Pyrus sp. in beech and black alder forests or in open places.

Distribution. In Poland $P$. arnoldii is a rare mountain species, known only from the Carpathians (Fig. 1). Most of the analyzed specimens originates from 1950-1960, and perhaps the species is close to extinction.

Parmotrema arnoldii is a temperate species of both, Northern and Southern Hemispheres. This taxon occurs in Europe, e.g., Austria (Hafellner, Türk 2001), Germany (Hale 1965; Scholtz 2000), Great Britain (Coppins 2002), France (Hale 1965), Ireland (Fox 2004), Scandinavia (Hale 1965; Santesson et al. 2004), Slovenia (Suppan et al. 2000), Spain (Llimona, Hladun 2001), Switzerland (Scheidegger et al. 2002) and Ukraine (Kondratyuk et al. 1998). Outside Europe it was reported from Macaronesia, Africa, Asia, and North and South Americas (e.g., Hale 1965; Hafellner 1995; Louwhoff 2009a; Pišút 2009).

Specimens examinated. Poland. Fd 95 - Beskid Mały Mts., Gładkie pass, above Przełęcz Kocierska pass, alt. ca $650 \mathrm{~m}$, on Acer platanoides, 10 Apr. 1962, leg. J. Nowak (KRAM-L 9466); the same locality, alt. ca 700 m, on Fraxinus excelsior, 4 Oct. 1962, leg. J. Nowak (KRAM-L 10004). Gd 59 - Tatry Mts., Dolina Białego valley, on Acer pseudoplatanus, 10 Aug. 1925, leg. J. Motyka (KRAM-L 10150). Ge 21 - Gorce Mts., near Kamienica village, in the Wojtasy forest, alt. 660 m, alder forest, on Alnus sp., 20 Aug. 1967, leg. K. Glanc (KRAM-L 35413). Gf 59 - Bieszczady Zachodnie Mts., Pszczeliny village, alt. 700 m, alder forest, on Alnus sp., 25 Sept. 1958, leg. K. Glanc (KRAM-L 35420, in the specimen of Parmotrema perlatum). Gf 68 - Bieszczady Zachodnie Mts., Bieszczadzki National Park, Beskidnik Mt., alt. 740 m, beech forest, on Fagus sylvatica, 28 Aug. 1957, leg. K. Glanc (KRAM-L 35425); by the Beskidnik stream, beech forest, on Fagus sylvatica, 1957, leg. K. Glanc (KRAM-L 35428). Gf 69 - Bieszczady Zachodnie Mts., Bieszczadzki National Park, Caryńskie village, near Przełęcz Przysłup pass, alt. 700 m, on Pyrus sp., Sept. 2005, leg. R. Kościelniak (KRAP).

Parmotrema crinitum (Ach.) M. Choisy, Bull. Mens. Soc. Linn. Soc. Bot. Lyon 21: 175 (1952).

Syn. Parmelia crinita Ach., Syn. Lich.: 196 (1814).

Characteristic of the species. Parmotrema crinitum is characterized by the presence of marginal and laminal isidia, which are often ciliate, lower surface black with a broad brown erhizinate marginal zone and the production of atranorin (cortex) and stictic acid complex, including menegazziaic acid (medulla). Isidia wary from sparse, simple, cylindrical or lobulate to coralloid-branched and forming dense clusters. Cortex reacts $\mathrm{K}+$ yellow, whereas medulla is $\mathrm{C}-, \mathrm{K}+$ yellow, $\mathrm{KC}+$ yellow, $\mathrm{PD}+$ yellow-orange (Hale 1965; Louwhoff 2009a). The chemistry agrees well with that reported by Hale (1965) and Louwhoff (2009a).

Affinities. The species is easily recognizable by the presence of isidia, broad bare marginal zone and the production of stictic acid complex. Parmelinopsis horrescens (Taylor) Elix \& Hale also has ciliate-isidia, but it is distinguished by the smaller thallus, the lower surface that is rhizinate to the margins and the lack of stictic acid complex (Louwhoff 2009b). So far this species has not been found in Poland.

Marginal and laminal isidia of similar shape to those present in Parmotrema crinitum are present also in Platismatia glauca (L.) W. L. Culb. \& C. F. Culb., but that species lacks cilia, does not react with PD (stictic acid complex absent) and produces caperatic acid (Culberson, Culberson 1968).

Habitat requirements: The species usually grows on bark of deciduous trees in old forests or in open situations (Fałtynowicz 2003; Louwhoff 2009a). In Poland it 


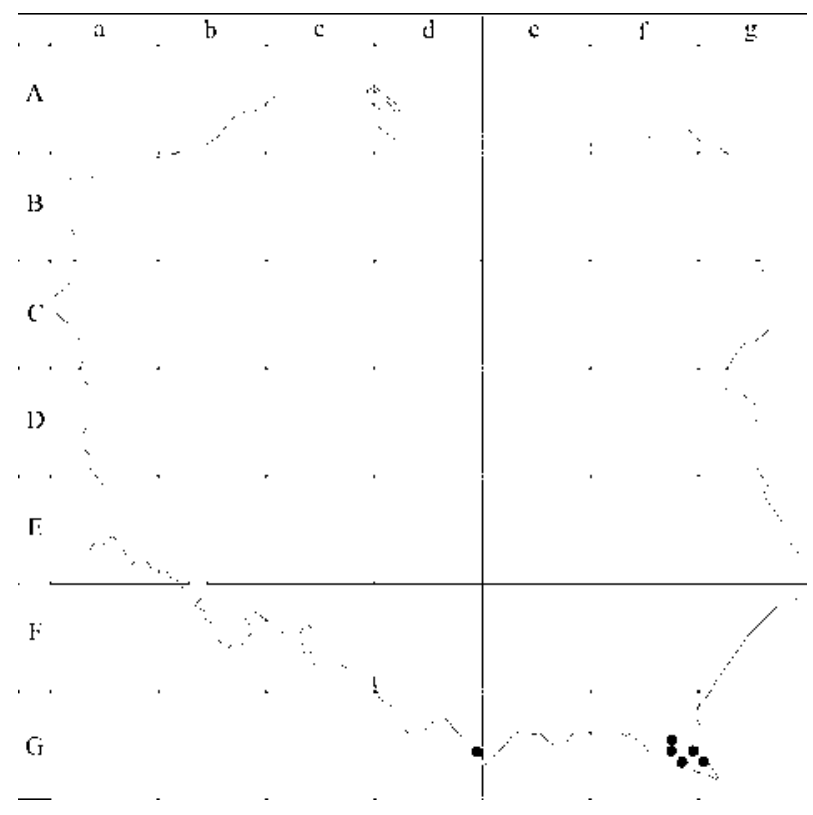

Fig. 2. Distribution of Parmotrema crinitum in Poland in the ATPOL grid square system.

was so far reported only as epiphyte on Abies alba, Acer pseudoplatanus, Alnus spp., Fagus sylvatica (ca 58\% of Polish records) and Picea abies, usually in beech forests or along streams.

Distribution. According to Fabiszewski (1968) and Fałtynowicz (2003 and literature cited therein) P. crinitum was reported from the Carpathians and Sudety Mts., however this study confirm its occurrence in the Carpathians (material from Sudety Mts. not traced). Known distribution of the species is presented on figure 2. This lichen is known only from old collections, and perhaps it is already extinct in the territory of Poland.

P. crinitum is a cosmopolitan species, widespread throughout tropical and temperate areas and even subboreal forests (Hale 1965; Louwhoff 2009a). It was reported in Europe from, e.g., Austria (Hafellner, Türk 2001), Belgium (Diederich et al. 2009), the Czech Republic (Liška et al. 2008), France and Hungary (Hale 1965), Germany (Scholz 2000), Great Britain (Hale 1965; Coppins 2002), Italy (Hale 1965), Ireland (Fox 2004), Luxembourg (Diederich et al. 2009), Portugal (Hale 1965), Scandinavia (Hale 1965; Santesson et al. 2004), Slovakia (Lisická 2005), Slovenia (Suppan et al. 2000), Spain (Hale 1965) and Ukraine (Kondratyuk et al. 1998). Outside Europe it is known from Africa, Asia, Australia, Macaronesia, and North and South America (e.g., Hale 1965; Hafellner 1995; Louwhoff and Elix 1999; Louwhoff 2009a; McCarthy 2009).

Specimens examinated. Poland. Gd 59 - Tatry Zachodnie Mts., Łysanki Mt., on Picea abies, 29 Aug. 1925, leg. J. Motyka (KRAM-L 10138). Gf 47 - Bieszczady Zachodnie Mts., by Solinka river, beech forest, on Abies alba, 13 Aug. 1956, leg. K. Glanc (KRAM-L 36990). Gf 57 - Bieszczady Zachodnie Mts., Falowa Mt., SE of Cisna village, on Alnus sp., 17 June 1954, leg. T. Sulma (UGDA-L 2561); Krywe village, by Dołżycki stream, near road to Dołżyca village, alt. $600 \mathrm{~m}$, on Alnus sp., 28 June 1958, leg. K. Glanc (KRAM-L 36987). Gf 59 - Bieszczady Zachodnie Mts., Stuposiany village, alt. 640 m, beech forest, on 
Fagus sylvatica, 23 June 1957, leg. K. Glanc (KRAM-L 36988); SE of Pszczeliny village, alt. $690 \mathrm{~m}$, by the stream, on Abies alba, 29 June 1959, leg. K. Glanc (KRAM-L 38926); W of Pszczeliny village, alt. 700 m, alder forest, on Alnus sp., 24 Sept. 1958, leg. K. Glanc (KRAM-L 36993). Gf 68 - Bieszczady Zachodnie Mts., Bieszczadzki National Park, by Beskidnik stream, alt. 740 m, beech forest, on Acer pseudoplatanus, 1 Sept. 1962, leg. K. Glanc (UGDA-L 12243); Beskidnik Mt., alt. 740 m, beech forest, on Fagus sylvatica, 28 Aug. 1957, leg. K. Glanc (KRAM-L 36991); near Wetlina village, by Wielki Bukowy stream, ca alt. 750 m, beech forest, on Fagus sylvatica, 18 Aug. 1958, leg. Z. Tobolewski (UGDA-L 4476); by Wielki Lutowy stream, alt. ca 750 m, beech forest, on Fagus sylvatica, 18 Aug. 1958, leg. K. Glanc (KRAM-L 36994, 36996, 35997, 36999 \& 37000); S slope of Dział Mt., beech forest, on Fagus sylvatica, 19 Aug. 1958, leg. K. Glanc (KRAM-L 35998 \& 36989). Gg 60 - Bieszczady Zachodnie Mts., Bieszczadzki National Park, S slope of Tarnica Mt., alt. 900 m, beech forest, on Fagus sylvatica, 22 June 1956, leg. K. Glanc (KRAM-L 36992). Poorly localized specimen. Tatra Mts., 1889, leg. W. Boberski (KRAM-L 20176).

Parmotrema perlatum (Huds.) M. Choisy., Bull. Mens. Soc. Linn. Soc. Bot. Lyon 21: 174 (1952).

Syn. Lichen perlatus Huds., Fl. Angl.: 448 (1762), Parmelia perlata (Huds.) Ach., Meth. Lich.: 214 (1803), Parmotrema chinense auct. non (Osbeck) Hale \& Ahti.

Characteristic of the species. The diagnostic characters of $P$. perlatum are the conspicuous submarginal soralia, revolute lobes, narrow, shiny and often rugose naked zone of lower side along the margin. The species contains atranorin, stictic acid complex, including stictic, constictic and menegazziaic acids with other related substances. Cortex reacts $\mathrm{K}+$ yellow, whereas medulla is $\mathrm{C}-, \mathrm{K}+$ yellow and $\mathrm{PD}+$ orange(Louwhoff 2009a). The chemistry of Polish agrees with the previously reported results.

Affinities. Parmotrema perlatum can be separated from other sorediate and marginally ciliate species, $P$. arnoldii (Du Rietz) Hale and P. robustum (Degel.) Hale, by the presence of stictic acid complex (Hale 1965; Louwhoff 2009a). In the spot test

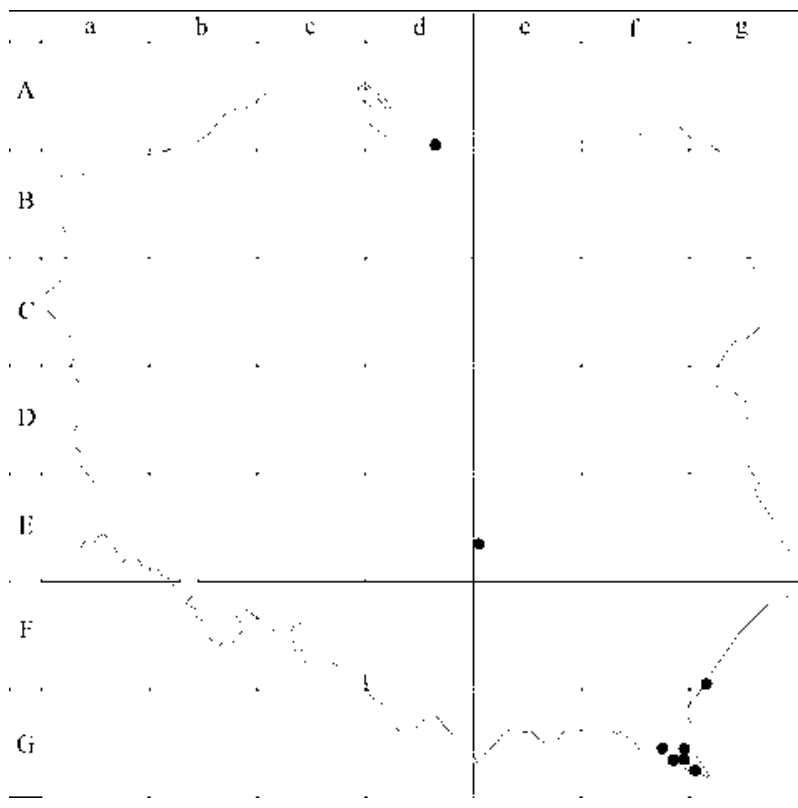

Fig. 3. Distribution of Parmotrema perlatum in Poland in the ATPOL grid square system. 
reactions, $P$. perlatum is similar to $P$. reticulatum (Taylor) M. Choisy, but the latter is readily distinguished by the network of hair-line cracks on the upper surface, the soredia at tips of incised lobe margins and the presence of salazanic acid (Louwhoff 2009a); so far it has not been reported from Poland.

Few specimens of $P$. perlatum were found under Cetrelia cetrarioides (Delise \& Duby) W. L. Culb. \& C. F. Culb. s.l. This taxon, and also other Cetrelia species also develop wide lobed thalli, but they differ in the presence of pseudocyphellae, eciliate thallus margin and they never produce stictic acid complex (Culberson, Culberson 1968; Obermayer, Mayrhofer 2007). Also Platismatia glauca is morphologically similar to Parmotrema perlatum, but it lacks marginal cilia, has isidia and a different chemistry (caperatic acid) (Culberson, Culberson 1968).

Habitat requirements. Parmotrema perlatum is sensitive to air pollution and occurs on well-lit, neutral to somewhat acid-barked, broad-leaved trees, also frequently on siliceous rocks and walls, coastal rocks, usually where illumination is moderate to good (Lowhoff 2009a). In Poland this lichen was found mostly on bark of Alnus spp. and Fagus sylvatica, but single specimens were also collected on bark of Fraxinus excelsior and Picea abies.

Distribution. In Poland $P$. perlatum was reported several times from southern Poland (Fałtynowicz 2003). After the revision of all available specimens most of those records appeared to be correct. Some additional localities are added here, with records from Northern and Central Poland (the locality from Central Poland also included in paper by Łubek 2009). The known distribution of the species is presented on figure 3. As all examined specimens were collected before 1960, the species is perhaps close to extinction.

The species is a cosmopolitan lichen widespread throughout temperate and tropical areas (Hale 1965; Louwhoff 2009a), known from many European countries, e.g., Austria (Hafellner, Türk 2001), Belgium (Diederich et al. 2009), the Czech Republic (Liška et al. 2008), France (Hale 1965), Germany (Scholtz 2000), Great Britain (Coppins 2002), Ireland (Hale 1965), Italy (Hale 1965), Luxembourg (Diederich et al. 2009), the Netherlands (Hale 1965; Aptroot et al. 2004), Portugal (Hale 1965), Scandinavia (Santesson et al. 2004), Slovakia (Lisická 2005), Spain (Hale 1965; Llimona, Hladun 2001) and Ukraine (Kondratyuk et al. 1998). The species has been also recorded from Macaronesia, Africa, Asia, Australia, North America and South America (e.g. Hale 1965; Hafellner 1995; Louwhoff, Elix 1999; McCarthy 2009; Pišút 2009).

Specimens examinated. Poland. Ad 96 - Wysoczyzna Elbląska high plain, Brzozowo forest district, NE of Milejewo village, old beech forest, on Fagus sylvatica, 20 July 1957, leg. T. Sulma (UGDA-L 15000). Ee 60 - Wyżyna Przedborska upland, Niecka Włoszczowska basin, near Oleszno nature reserve, forest section no. 73, on Fraxinus excelsior, 11 March 2008, leg. A. Łubek (KTC). Eg 91 - Roztocze Środkowe, Zwierzyniec village, by Świerszcz river, on Alnus glutinosa, 1969, leg. J. Bystrek (LBL). Gf 57 - Bieszczady Zachodnie Mts., W slope of Krzemienna Mt., alt $650 \mathrm{~m}$, on Picea abies, 28 July 1958, leg. K. Glanc (KRAM-L 37051); Krywe, by the road to Dołżyca village, by Dołżycki stream, ca $580 \mathrm{~m}$, on Alnus glutinosa, 28 July 1958, leg. K. Glanc (KRAM-L 37050, in specimen of Cetrelia cetrarioides s.1.); near Krywe village, by the turist path to Cisna village, alt. $550 \mathrm{~m}$, alder forest, by the stream, on Alnus sp., 30 July 1958, leg. K. Glanc (KRAM-L 35416); Cisna village, by the road to Krywe village, alt. $550 \mathrm{~m}$, alder forest, by the stream, on Alnus sp., 30 July 1958, leg. K. Glanc (KRAM-L 35418); SE of Cisna village, slopes of Falowa Mt., in deep gorge, on Alnus sp. and bark of unidentified tree, 17 July 1954, leg. T. Sulma (UGDA-L 2511 \& 2528). Gf 59 - Bieszczady Zachodnie Mts., Pszczeliny village, $S$ of Stuposiany village, alt. ca $650 \mathrm{~m}$, mixed forest by the stream, on Alnus sp., 25 Sept. 1958, leg. Z. Tobolewski (UGDA-L 4477); Pszczeliny 
village, alt. 700 m, alder forest, on Alnus sp., 25 Sept. 1958, leg. K. Glanc (KRAM-L 35420); the same locality, 24 Sept. 1958, leg. K. Glanc (UGDA-L 35422). Gf 68 - Bieszczady Zachodnie Mts., Bieszczadzki National Park, by Beskidnik stream, on Fagus sylvatica, s.dat., leg. K. Glanc (KRAM-L 35429); by Wielki Lutowy stream, alt. ca 750 m, beech forest, on Fagus sylvatica, 18 Aug. 1959, leg. K. Glanc (KRAM-L 36994, 36996 \& 35997, all admixed in specimens of Parmotrema crinitum). Gf 69 - Bieszczady Zachodnie Mts., Bieszczadzki National Park, Bereżki village, by the Wołosaty stream, alt. $600 \mathrm{~m}$, on Alnus sp., 21 Sept. 1958, leg. K. Glanc (KRAM-L 37055); the same locality, 22 Sept. 1958, leg. K. Glanc (KRAM-L 35424); near road to Wołosatka stream, alt. $840 \mathrm{~m}$, on Fagus sylvatica, 22 June 1956, leg. Z. Tobolewski (KRAM-L 35419); by the Rzeczyca stream, by the road between villages Ustrzyki Gorne and Brzegi (Berehy) Górne, alt. 680 m, alder forest, on Alnus sp., 27 Aug. 1957, leg. K. Glanc (KRAM-L 35423); the same locality, 7 July 1959, leg. K. Glanc (KRAM-L 35415); SE of Pszczeliny village, alt. $690 \mathrm{~m}$, by the stream, on Alnus sp., 29 July 1959, leg. K. Glanc (KRAM-L 35414). Gg 70 - Bieszczady Zachodnie Mts., Bieszczadzki National Park, by the Wołosatka stream, near Tarnica Mt., alt. 840 m, on Fagus sylvatica, 21 June 1956, leg. K. Glanc (KRAM-L 35417).

Parmotrema stuppeum (Taylor) Hale, Phytologia 28: 339 (1974).

Syn. Parmelia stuppea Taylor, London J. Bot. 6: 175 (1847); for more synonyms see Hale (1965).

Characteristic of the species. Parmotrema stuppeum is characterized by thallus loosely attached to the bark, black and sparsely rhizinate lower surface, continuous (not finely reticulately cracked) upper cortex, soralia formed on the top of laciniae and the presence of atranorin in cortex and salazinic acid in medulla (Hale 1965; Sipman 2005). Cortex reacts $\mathrm{K}+$ yellow, whereas medulla is $\mathrm{C}$ and $\mathrm{KC}-, \mathrm{K}+$ yellow turning red, and PD+ orange-red. The chemistry of Polish specimens agrees with previously reported information.

Affinities. The species can be separated from other sorediate Parmotrema species with continuous cortex by the presence of salazinic acid. This substance is produced by $P$. reticulatum (Tayl.) M. Choisy [syn. Rimelia reticulata (Tayl.) Hale \& Fletcher] and $P$. subreticulatum (Tav.) Hale, but these taxa has finely, but distinctly reticulately cracked and maculate upper cortex (Hale 1965; Sipman 2005; Louwhoff 2009a); so far they have not been reported from Poland.

In Poland most specimens of $P$. stuppeum were determined as $P$. chinense, a synonym of $P$. perlatum (see above). Both taxa have PD+ orange to orange-red medulla, but it is due to salazinic acid in $P$. stuppeum, whereas in $P$. perlatum the reaction is caused by stictic acid and related substances. They can also be separated without TLC; medulla of $P$. perlatum is $\mathrm{K}+$ yellow, but in $P$. stuppeum the yellow colour turns red (Hale 1965; Sipman 2005; Louwhoff 2009a).

Habitat requirements. In Poland $P$. stuppeum is a corticolous lichen. It was collected almost exclusively on Fagus sylvatica, but once it was found on bark of Pyrus communis.

Distribution. In Poland the species has been so far reported only once by Sulma and Fałtynowicz (1988). Here we report three new localities, two from Bieszczady Mts. and one from Roztocze. The known distribution of the species is presented on figure 4. It appears as a rare and an endangered lichen in Poland, as only one contemporary record is known.

According to Hale (1965) P. stuppeum is common in the mountain of North America, central America and Europe; in Africa and Asia it is more rare. In Europe the species has been reported from Austria (Hafellner, Türk 2001), the Czech Republic (Liška et al. 2008), Germany (Hale 1965; Scholtz 2000), Portugal (Hale 1965), Spain (Llimona, Hladun 2001), Switzerland (Scheidegger et al. 2002) and 


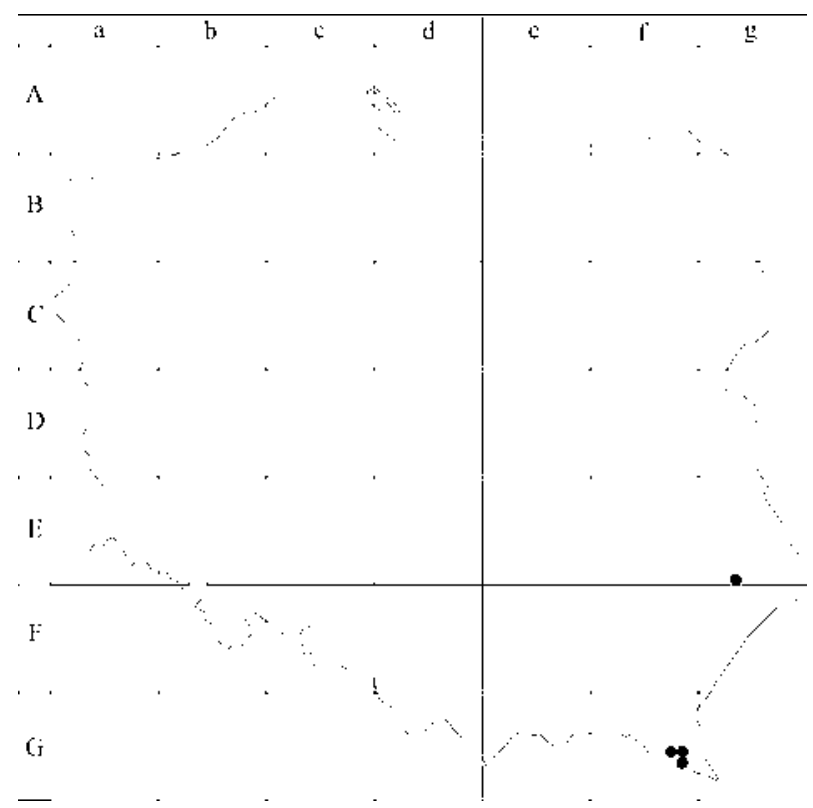

Fig. 4. Distribution of Parmotrema stuppeum in Poland in the ATPOL grid square system.

Ukraine (Kondratyuk et al. 1998). It was also reported from the Netherlands, but it has been recently considered as misidentification; the records belong to $P$. subreticulatum (Aptroot et al. 2008).

Specimens examinated. Poland. Eg 93 - Roztocze Środkowe, Majdan Ruszowski village, 50³7'N, $23^{\circ} 18^{\prime} \mathrm{E}$, on Fagus sylvatica, 21 Aug. 1933, leg. T. Sulma (UGDA-L 2555). Gf 57 - Bieszczady Zachodnie Mts., S slope of Łopiennik Mt., alt. ca 950 m, on Fagus sylvatica, 30 June 1958, leg. K. Glanc (KRAM-L 35421). Gf 58 - Bieszczady Zachodnie Mts., Bieszczadzki Park Narodowy, Suche Rzeki, alt. 670 m, on Pyrus communis, Aug. 1995, leg. R. Kościelniak (KRAP). Gf 68 - Bieszczady Zachodnie Mts., by Beskidnik stream, beech forest, on Fagus sylvatica, 1957, leg. K. Glanc (KRAM-L 35426, UGDA-L 3547, also in specimen of Parmotrema arnoldii, KRAM-L 35428); the same locality, on Fagus sylvatica, s.dat., leg. K. Glanc (KRAM-L 35429, as a mixture in specimen of P. perlatum).

\section{CONCLUSIONS}

Four species of Parmotrema are known to occur in Poland, P. arnoldii, P. crinitum, $P$. perlatum and $P$. stuppeum. They have been mainly found in southern part of the country, mostly in the Carpathians. Only P. perlatum is known from two localities in northern and central Poland.

The study has shown, that the secondary lichen metabolites are very useful character in determination of species; the analyzes of lichen secondary metabolites led to discovery of 3 new localities of $P$. stuppeum. So far the species has been reported only from one locality. 
At present, only $P$. perlatum and $P$. stuppeum are known to be represented by recent collections. It appeared, that $P$. arnoldii and $P$. crinitum have not been collected since 1962. Thus, all Parmotrema species should be considered as in great danger of extinction in Poland. Possibly two of them, $P$. arnoldii and $P$. crinitum, are already extinct in Poland.

Acknowledgements. We are grateful to the Curators of herbaria for the loan of specimens and the reviewer for helpful comments. This paper is dedicated to Professor Krystyna Czyżewska (Łódź) on the occasion of her anniversary.

\section{REFERENCE}

Aptroot A., Herk, van C. M., Sparrius L. B., Spier J. L. 2004. Checklist van de Nederlandse korstmossen en korstmosparasieten. Buxbaumiella 69: 17-55.

Aptroot A., Spier J. L., Jordaens D. 2008. Parmotrema pseudoreticulatum, de verbeterde determinatie van Parmotrema stuppeum (Gewimperd schildmos). Buxbaumiella 80: 9-12.

Blanco O., Crespo A., Divakar P. K., Elix J. A., Lumbsch H. T. 2005. Molecular phylogeny of parmotremoid lichens (Ascomycotina, Parmeliaceae). Mycologia 97: 150-159.

Blanco O., Crespo A., Elix J. A., Hawksworth D. L., Lumbsch H. T. 2004a. A molecular phylogeny and a new classification of parmelioid lichens containing Xanthoparmelia-type lichenan (Ascomycota: Lecanorales). Taxon 53 (4): 959-975.

Blanco O., Crespo A., Divakar P. K., Esslinger T. L., Hawksworth D. L., Lumbsch H. T. 2004b. Melanelixia and Melanohalea, two new genera segregated from Melanelia (Parmeliaceae) based on molecular and morphological data. Mycol. Res. 108 (8): 873-884.

Blanco O., Crespo A., Ree R. H., Lumbsch H. T. 2006. Major clades of parmelioid lichens (Parmeliaceae, Ascomycota) and the evolution of their morphological and chemical diversity. Mol. Phyl. Evol. 39: $52-69$.

Cieśliński S., Fałtynowicz W. 1993. Note from editors. (In:) S. Cieśliński, W. Fałtynowicz (eds), Atlas of the geographical distribution of lichens in Poland. 1: 7-8. W. Szafer Institute of Botany of Polish Academy of Sciences, Kraków.

Coppins B. J. 2002. Checklist of lichens of Great Britain and Ireland. British Lichen Society, Huddersfield, $87 \mathrm{pp}$.

Culbersona W. L., Culberson C. F. 1968. The lichen general Cetrelia and Platismatia (Parmeliaceae). Contrib. U. S. Natl. Herb. 34 (7): 449-558.

Diederich P., Ertz D., Stapper N., Sérusiaux E., Broeck van den D., Boom van den P., Ries C. 2009. The lichens and lichenicolous fungi of Belgium, Luxembourg and northern France. http://www.lichenology.info [17.08.2009].

Divakar P. K., Crespo A., Blanco O., Lumbsch H. T. 2006. Phylogenetic significance of morphological characters in the tropical Hypotrachyna clade of parmelioid lichens (Parmeliaceae, Ascomycota). Mol. Phyl. Evol. 40: 448-458.

Elix J. A. 1993. Progress in the generic delimitation of Parmelia sensu lato lichens (Ascomycotina: Parmeliaceae) and a synoptic key to the Parmeliaceae. Bryologist 96: 359-383.

Fabiszewski J. 1968. Porosty Śnieżnika Kłodzkiego i Gór Bialskich (studium florystyczno-ekologiczne). Monogr. Bot. 26: 1-115.

Fałtynowicz W. 2003. The lichens, lichenicolous and allied fungi of Poland. An annotated checklist. (In:) Z. Mirek (ed.). Biodiversity of Poland 6: 1-435. W. Szafer Institute of Botany of Polish Academy of Sciences, Kraków.

Fox H. 2004. Checklist of lichens and lichenicolous fungi of Ireland - Version 2. http://www.botanicgardens.ie/herb/census/llfchecklst.pdf [01.10.2009].

Hafellner J. 1995. A new checklist of lichens and lichenicolous fungi of insular Laurimacaronesia including a lichenological bibliography for the area. Fritschiana (Graz) 5: 1-132.

Hafellner J., Türk R. 2001. Die lichenisierten Pilze Österreichs - eine Checkliste der bisher nachgewiesenen Arten mit Verbreitungsangaben. Stapfia 76: 1-167.

Hale M. E. 1965. A monograph of Parmelia subgenus Amphigymnia. Contrib. US Nat. Herb. 36: 193358. 
Hale M. E. 1974a. Bulbothrix, Parmelina, Relicina, and Xanthoparmelia, four new genera in the Parmeliaceae. Phytologia 28: 479-490.

Hale M. E. 1974b. Delimitation of the lichen genus Hypotrachyna (Vainio) Hale. Phytologia 28: 340342.

Hale M. E. 1975. A revision of the lichen genus Hypotrachyna (Parmeliaceae) in tropical America. Smithsonian Contrib. Bot. 25: 1-73.

Hale M. E. 1976a. A monograph of the lichen genus Bulbothrix Hale (Parmeliaceae). Smithsonian Contrib. Bot. 32: 1-29.

Hale M. E. 1976b. A monograph of the lichen genus Parmelina Hale (Parmeliaceae). Smithsonian Contrib. Bot. 33: 1-60.

Hale M. E. 1976c. Synopsis of a new lichen genus Everniastrum Hale (Parmeliaceae). Mycotaxon 3: 345353.

Hale M. E. 1986. Flavoparmelia, a new genus in the lichen family Parmeliaceae (Ascomycotina). Mycotaxon 25: 603-605.

Kondratyuk S. Ya., Khodosovtsev A. Ye., Zelenko S. D. 1998. The second checklist of lichen forming, lichenicolous and allied fungi of Ukraine. M. H. Kholodny Institute of Botany, Kiev, 179 pp.

Kukwa M., Motiejūnaitė J., Rutkowski P., Zalewska A. 2002. New or interesting records of lichenicolous fungi from Poland. Part I. Herzogia 15: 129-139.

Lisická E. 2005. The lichens of the Tatry Mountains. Veda, the Publishing House of the Slovak Academy of Sciences, Bratislava, 439 pp.

Liška J., Palice Z., Slavíková Š. 2008. Checklist and Red List of lichens of the Czech Republic. Preslia 80: 151-182.

Llimona X., Hladun N. L. 2001. Checklist of the lichens and lichenicolous fungi of the Iberian Peninsula and Balearic Islands. Bocconea 14: 1-581.

Louwhoff S. H. J. J. 2009a. Parmotrema A. Massal. (1860). (In:) C. W. Smith, A. Aptroot, B. J. Coppins, A. Fletcher, O. L. Gilbert, P. W. James, P. A. Wolseley (eds). The lichen flora of Great Britain and Ireland. Natural History Museum Publications, London: 661-663.

Louwhoff S. H. J. J. 2009b. Parmelinopsis Elix \& Hale (1987). (In:) C. W. Smith, A. Aptroot, B. J. Coppins, A. Fletcher, O. L. Gilbert, P. W. James, P. A. Wolseley (eds). The lichen flora of Great Britain and Ireland. Natural History Museum Publications, London: 658-659.

Louwhoff S. H. J. J., Elix J. A. 1999. Parmotrema and allied genera in Papua New Guinea. Biblioth. Lichenol. 73: 1-152.

Lumbsch H. T., Huhndorf S. M. (ed.) 2007. Outline of Ascomycota - 2007. Myconet 13: 1-58.

Łubek A. 2009. New records of lichens from uplands. Acta Mycol. 44 (2): 275-282.

McCarthy P. M. 2009. Checklist of the lichens of Australia and its Island territories. Australian Biological Resources Study, Canberra. Version 28 September 2009. http:/www.anbg.gov.au/abrs/lichenlist/ introduction.html [15.10.2009].

Obermayer W., Mayrhofer H. 2007. Hunting for Cetrelia chicitae (Lichenized Ascomycetes) in the Eastern European Alps (including an attempt for a morphological characterization of all taxa of the genus Cetrelia in Central Europe). Phyton 47 (1-2): 231-290.

Orange A., James P. W., White F. J. 2001. Microchemical methods for the identification of lichens. British Lichen Society, London, $101 \mathrm{pp}$.

Peršoh D., Rambold G. 2002. Phacopsis - a lichenicolous genus of the family Parmeliaceae. Mycol. Progr. $1(1): 43-55$.

Pišút I. 2009. Some lichens from the vicinity of Ribeiro Frio (Madeira island, Macaronesia). Acta Mycol. 44 (2): 179-184.

Purvis O. W., Coppins B. J., Hawksworth D. L., James P. W., Moore D. M. (eds). 1992. The lichen flora of Great Britain and Ireland. Natural History Museum Publications \& British Lichen Society, London, 710 pp.

Santesson R., Moberg R., Nordin A., Tønsberg T., Vitikainen O. 2004. Lichen-forming and lichenicolous fungi of Fennoscandia. Museum of Evolution, Uppsala University, Uppsala, 359 pp.

Scheidegger C., Clerc P., Dietrich M., Frei M., Groner U., Keller C., Roth I., Stofer S., Vust M. 2002. Rote Liste der gefährdeten Arten der Schweiz: Baum- und erdbewohnende Flechten. BUWAL-Reihe Vollzug Umwelt, Bundesamt für Umwelt, Wald und Landschaft BUWAL, Bern, und Eidgenössische Forschungsanstalt WSL, Birmensdorf, Conservatoire et Jardin botaniques de la Ville de Genève CJBG, 124 pp. 
Scholz P. 2000. Katalog der Flechten und flechtenbewohnenden Pilze Deutschlands. Schriftenreihe Vegetationsk. 31: 1-298.

Sipman H. J. M. 2005. MASON HALE's key to Parmotrema, revised edition: key to wide-lobed parmelioid species occurring in Tropical America (genera Canomaculina, Parmotrema, Rimelia, Rimeliella). http://www.anbg.gov.au/abrs/lichenlist/introduction.html [15.10.2009].

Sulma T., Fałtynowicz W. 1988. Materiały do rozmieszczenia porostów z rodziny Parmeliaceae w Polsce. Acta Mycol. 23 (1): 107-123.

Suppan U., Prügger J., Mayrhofer H. 2000. Catalogue of the lichenized and lichenicolous fungi of Slovenia. Biblioth. Lichenol. 76: 1-215.

Zając A. 1978. Atlas of distribution of vascular plants in Poland (ATPOL). Taxon 27: 481-484.

\section{Porosty z rodziny Parmeliaceae w Polsce. I. Rodzaj Parmotrema}

\section{Streszczenie}

W Polsce poznano dotychczas cztery gatunki z rodzaju Parmotrema, P. arnoldii, $P$. crinitum,

P. perlatum i P. stuppeum. Gatunki te były publikowane bez analizy wtórnych metabolitów, co mogło skutkować nieprawidłowym oznaczeniem części okazów. Obecnie zrewidowano cały dostępny materiał zielnikowy przy użyciu chromatografii cienkowarstwowej (TLC). W jej wyniku potwierdzono występowanie wszystkich czterech taksonów znanych dotychczas w kraju. W większości wypadków przedstawiciele tego rodzaju występują w Polsce Południowej, głównie w Karpatach. $P$. perlatum został podany także z jednego stanowiska w Polsce Północnej (Wysoczyzna Elbląska) i jednego - w Polsce Środkowej (Niecka Włoszczowska). Dla P. stuppeum podano trzy nowe stanowiska na terenie kraju; dotychczas porost ten znany był tylko z jednego stanowiska w Bieszczadach. Jak się wydaje, wszystkie potwierdzone gatunki są silnie zagrożone wyginięciem w kraju, gdyż większość okazów zbierana była przed rokiem 1960. Rozmieszczenie zrewidowanych taksonów przedstawiają ryciny 1-4. 